\title{
SLCO family of organic anion transporting polypeptides (version 2019.4) in the IUPHAR/BPS Guide to Pharmacology Database
}

\author{
Bruno Hagenbuch ${ }^{1}$
}

1. University of Kansas, USA

\begin{abstract}
The SLCO superfamily is comprised of the organic anion transporting polypeptides (OATPs). The 11 human OATPs are divided into 6 families and ten subfamilies based on amino acid identity. These proteins are located on the plasma membrane of cells throughout the body. They have 12 TM domains and intracellular termini, with multiple putative glycosylation sites. OATPs mediate the sodium-independent uptake of a wide range of amphiphilic substrates, including many drugs and toxins. Due to the multispecificity of these proteins, this guide lists classes of substrates and inhibitors for each family member. More comprehensive lists of substrates, inhibitors, and their relative affinities may be found in the review articles listed below.
\end{abstract}

\section{Contents}

This is a citation summary for SLCO family of organic anion transporting polypeptides in the Guide to Pharmacology database (GtoPdb). It exists purely as an adjunct to the database to facilitate the recognition of citations to and from the database by citation analyzers. Readers will almost certainly want to visit the relevant sections of the database which are given here under database links.

GtoPdb is an expert-driven guide to pharmacological targets and the substances that act on them. GtoPdb is a reference work which is most usefully represented as an on-line database. As in any publication this work should be appropriately cited, and the papers it cites should also be recognized. This document provides a citation for the relevant parts of the database, and also provides a reference list for the research cited by those parts.

Please note that the database version for the citations given in GtoPdb are to the most recent preceding version in which the family or its subfamilies and targets were substantially changed. The links below are to the current version. If you need to consult the cited version, rather than the most recent version, please contact the GtoPdb curators.

\section{Database links}

SLCO family of organic anion transporting polypeptides

http://www.guidetopharmacology.org/GRAC/FamilyDisplayForward?familyld=238

Transporters

OATP1A2

http://www.guidetopharmacology.org/GRAC/ObjectDisplayForward?objectld=1219

OATP1B1 
http://www.guidetopharmacology.org/GRAC/ObjectDisplayForward?objectld=1220

OATP1B3

http://www.guidetopharmacology.org/GRAC/ObjectDisplayForward?objectld=1221

OATP1C1

http://www.guidetopharmacology.org/GRAC/ObjectDisplayForward?objectld=1222

OATP2A1

http://www.guidetopharmacology.org/GRAC/ObjectDisplayForward?objectld=1223

OATP2B1

http://www.guidetopharmacology.org/GRAC/ObjectDisplayForward?objectld=1224

OATP3A1

http://www.guidetopharmacology.org/GRAC/ObjectDisplayForward?objectld=1225

OATP4A1

http://www.guidetopharmacology.org/GRAC/ObjectDisplayForward?objectld=1226

OATP4C1

http://www.guidetopharmacology.org/GRAC/ObjectDisplayForward?objectld=1227

OATP5A1

http://www.guidetopharmacology.org/GRAC/ObjectDisplayForward?objectld=1228

OATP6A1

http://www.guidetopharmacology.org/GRAC/ObjectDisplayForward?objectld=1229

\section{References}

1. Bailey DG, Dresser GK, Leake BF and Kim RB. (2007) Naringin is a major and selective clinical inhibitor of organic anion-transporting polypeptide 1A2 (OATP1A2) in grapefruit juice. Clin. Pharmacol. Ther. 81: 495502 [PMID:17301733]

2. Chan BS, Satriano JA, Pucci M and Schuster VL. (1998) Mechanism of prostaglandin E2 transport across the plasma membrane of HeLa cells and Xenopus oocytes expressing the prostaglandin transporter "PGT". J. Biol. Chem. 273: 6689-97 [PMID:9506966]

3. Fehrenbach T, Cui Y, Faulstich H and Keppler D. (2003) Characterization of the transport of the bicyclic peptide phalloidin by human hepatic transport proteins. Naunyn Schmiedebergs Arch. Pharmacol. 368: 415-20 [PMID:14530907]

4. Fischer WJ, Altheimer S, Cattori V, Meier PJ, Dietrich DR and Hagenbuch B. (2005) Organic anion transporting polypeptides expressed in liver and brain mediate uptake of microcystin. Toxicol. Appl. Pharmacol. 203: 257-63 [PMID:15737679]

5. Gui C, Obaidat A, Chaguturu R and Hagenbuch B. (2010) Development of a cell-based high-throughput assay to screen for inhibitors of organic anion transporting polypeptides 1B1 and 1B3. Curr Chem Genomics 4: 1-8 [PMID:20448812]

6. Kanai N, Lu R, Satriano JA, Bao Y, Wolkoff AW and Schuster VL. (1995) Identification and characterization of a prostaglandin transporter. Science 268: 866-9 [PMID:7754369]

7. Karlgren M, Vildhede A, Norinder U, Wisniewski JR, Kimoto E, Lai Y, Haglund U and Artursson P. (2012) Classification of inhibitors of hepatic organic anion transporting polypeptides (OATPs): influence of protein expression on drug-drug interactions. J. Med. Chem. 55: 4740-63 [PMID:22541068]

8. Noé J, Portmann R, Brun ME and Funk C. (2007) Substrate-dependent drug-drug interactions between gemfibrozil, fluvastatin and other organic anion-transporting peptide (OATP) substrates on OATP1B1, OATP2B1, and OATP1B3. Drug Metab. Dispos. 35: 1308-14 [PMID:17470528]

9. Treiber A, Schneiter R, Häusler S and Stieger B. (2007) Bosentan is a substrate of human OATP1B1 and OATP1B3: inhibition of hepatic uptake as the common mechanism of its interactions with cyclosporin $A$, rifampicin, and sildenafil. Drug Metab. Dispos. 35: 1400-7 [PMID:17496208]

10. Vavricka SR, Van Montfoort J, Ha HR, Meier PJ and Fattinger K. (2002) Interactions of rifamycin SV and rifampicin with organic anion uptake systems of human liver. Hepatology 36: 164-72 [PMID:12085361] 
